UDC 624.042

\title{
STOCHASTIC CALCULATION OF A QUASI-HOMOGENEOUS BOLTED JOINTS OF THE BODY SHEETS OF THE STEEL SILOS
}

\author{
Pichugin Sergii ${ }^{1}$, Makhinko Anton ${ }^{2}$, Makhinko Nataliia ${ }^{3 *}$ \\ ${ }^{1}$ Poltava National Technical Yuri Kondratyuk University https://orcid.org/0000-0001-8505-2130 \\ ${ }^{2}$ ETUAL LLC https://orcid.org/0000-0002-9147-7087 \\ ${ }^{3}$ National Aviation University https://orcid.org/0000-0001-8120-6374 \\ *Corresponding author E-mail: pasargada1985@gmail.com
}

This paper deals with the study of reliability of quasi-homogeneous bolted joints of the body of thin-walled constructions of the steel silos. Heterogeneity of this unit can be caused by number of reasons, in particular by presence of bolts of different strength in joint. In such case the reliability of the system is determined trough the probability of trouble-free work of the coefficient of the critical factor. The general conception of stochastic calculation consists in using the Monte-Karlo simulation procedure for the samples of random values of the large volume. It was formed the system of conditions, under which the reliability of joints is provided and analytical expressions for the value of coefficient of the critical factor is got, and also made practical calculation example with the following graphic presentation on a special coordinate plane - a critical stochastic scale. It was illustrated that random presence of bolts of less strength in field joint rapidly increases the risk of refusal.

Keywords: cylindrical silos, reliability, stochastic calculation, probability of the trouble-free work, quasi-homogeneous bolted joint, coefficient of the critical factor.

\section{ІМОВІРНІСНИЙ РОЗРАХУНОК КВАЗІОДНОРІДНИХ БОЛТОВИХ З'ЄДНАНЬ ЛИСТІВ КОРПУСУ СТАЛЕВИХ СИЛОСІВ}

\author{
Пічугін С.Ф. ${ }^{1}$, Махінько А.В. ${ }^{2}$, Махінько Н.O. ${ }^{3 *}$ \\ ${ }^{1}$ Полтавський національний технічний університет імені Юрія Кондратюка \\ 2 ТОВ ЕТУАЛЬ \\ ${ }^{3}$ Національний авіаційний університет \\ *Адреса для листування E-mail: pasargada1985@gmail.com
}

Стаття присвячена актуальній проблематиці дослідження надійності квазіоднорідних болтових з'єднань корпусу циліндричних сталевих силосів. У багатьох випадках проектна надійність таких стиків відрізняється від фактичних показників їх безвідмовної роботи. Джерелом цього є ряд об'єктивних причин, до числа яких можна віднести недоліки монтажних операцій, зокрема присутність болтів різного класу міцності, відсутність декількох болтів 3'єднання, розкручування кріплення болта в процесі експлуатації споруди чи недокрут на монтажі й інші чинники такого типу. У цьому випадку надійність системи визначалася через імовірність безвідмовної роботи з використанням коефіцієнта критичного фактора. Відмова болтового з'єднання однозначно визначалася як перевищення випадковим напруженням випадкового рівня границі текучості сталі. Загальна концепція ймовірнісного розрахунку полягала у використанні імітаційної процедури Монте-Карло для вибірок випадкових величин великого об'єму. Увага концентрувалася на розрахунковій ситуації, коли болти з'єднання складаються з трьох незалежних вибірок. Була сформульована система умов, при якій забезпечується надійність з'єднання й отримані аналітичні вирази для величини коефіцієнта критичного фактора. Наведено практичний приклад розрахунку з наступним графічним представленням на спеціальній координатній площині - критичній імовірнісній шкалі. Проілюстровано, що випадкова наявність болтів менших класів міцності в монтажному стику стрімко збільшує ризик відмови. Установлено, що показники ймовірності безвідмовної роботи однорідних та квазіоднорідних болтових з'єднань значно різняться лише при великих значеннях коефіцієнтів варіації значень зусилля. Показано, що навіть за відсутності мінливості значень міцності болтів випадкова величина критичного фактора буде зростати при постійному значенні показника надійності.

Ключові слова: циліндричний силос, надійність, імовірнісний розрахунок, імовірність безвідмовної роботи, квазіоднорідне болтове з'єднання, коефіцієнт критичного фактора. 


\section{Introduction}

The problem of reliability assessment is one $f$ the most important scientific problems that arise in the area of the building construction's calculation. It is connected not only with obtaining on its results more justified results from the economic point of view, but also with general entity of the term reliability. Depending from the chosen index, the reliability serves as a qualitative and quantitative indicator of the whole complex of constuction's properties. Considering the problem of stochastic calculation of bolted joint of the elements of steel silos, we need to pay attention to the problem connected first of all with features of this class of construction - usage of thin-walled core and sheet corrugated elements, high level of load, etc.

Also, due to the large number of accidents caused by numerous mounting errors, the second most important consideration when determining the level of reliability connection is taking into account the most common construction defaults that arise in the construction process.

\section{Review of the research sources and publications}

The assessment of the stress-strain state and the problem of determining the strength of bolted joints of metal structures, including thin-walled elements, remain urgent, which often can be found in the scientific publications $[1-4]$. We will note that among them there are important applied problems of analytical and numerical calculation of the bolted joints of the composite thinwalled constructions with considering features of friction, corrugation, presence of sealing gaskets, etc. [5, 6], and also numerical and experimental studies [7, 8]. Traditionally, the area of stochastic calculation remains less studied, which is certainly caused by the complexity of mathematical transformations and the large amount of theoretical knowledge in the field of probability theory and mathematical statistics [9-10]. The modern studies of the outlined issues have repeatedly been raised in the works of Pichugin S.F. and students of his Reliability Science School [11 - 14].

\section{Definition of unsolved aspects of the problem}

In the practice of designing units of thin-walled constructions of steel silos, the bolted joints of elements became widespread. In many cases, the design reliability of such joints differs from the actual indicators of their trouble-free work. The source of this is a number of objective reasons, which include the disadvantages of installation operations - wrong tightening of bolts or the use of fastening elements of the non-design class of strength. In this case, the classic strength analysis of the bolted joint, as in the analytical form, so in the application of finite element apparatus, requires not only the change of the initial data of the solved problem, but also the correction of a number of influential factors. These features are beyond the guidance of regulatory documents, and, accordingly, are overlooked in the process of engineering calculations. As well as the stock values, the reliability levels of bolted connections made with mounting defects remain unknown. Their assessment is an important task that requires thorough consideration and detailed scientific analysis.

\section{Problem statement}

The main purpose of this study is the stochastic analysis of the heterogeneous bolted joint of thin-walled elements of the steel silo body. The heterogeneity of such a unit can be caused by a number of reasons, including the presence of bolts of different strength class, the absence of several connection bolts, untwisting of the bolt attachment during the exploitation period of the construction or short of rotation during mounting and other factors of a similar nature.

\section{Basic material and results}

The main structural elements of the body of the steel silos are the thin-walled elements of the corrugated sheets and the vertical stiffeners, which are interconnected by bolts made with gap and pre-tightening. The fasteners, which are used in the connection (fig. 1), consist of bolts and nuts, which are zinc-coated, and of sealing washers. Mostly, the structural units are designed for bolts of strength of classes 5.8 for the roof and 8.8 and 10.9 for the body of the capacity.

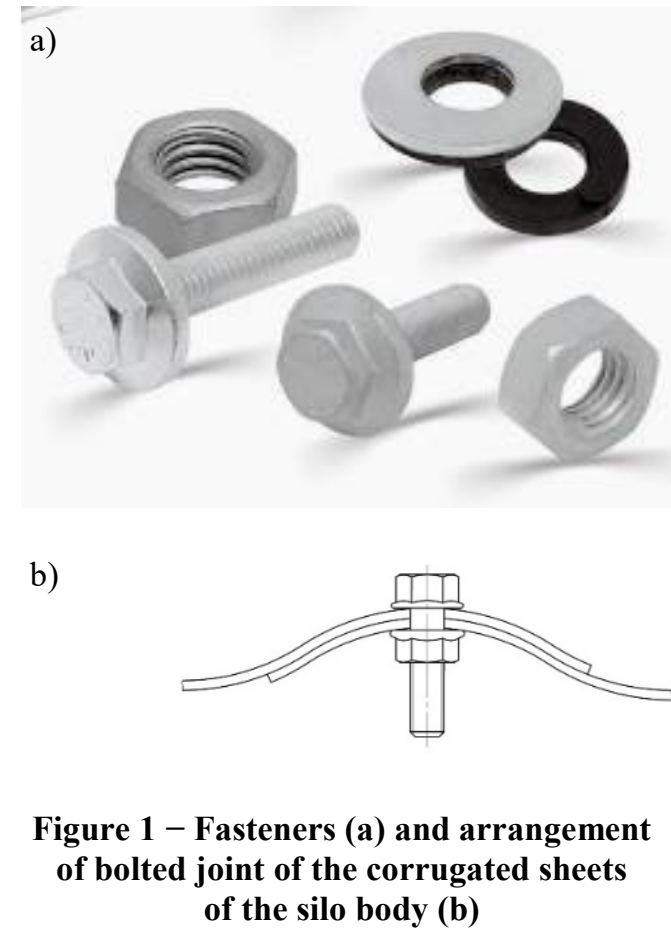

For the basic indicator of the quantitative measure of reliability when calculating the bolted connections, we take the coefficient of the critical factor, which is equal to the ratio of the random effort $\tilde{S}$ and the generalized strength $\tilde{R}$

$$
\tilde{K}_{R}=\frac{\tilde{S}}{\tilde{R}} \leq 1,0 .
$$

The main models of the failure are the cut of the bolt and the bearing of the metal of the connected elements in the hole. In general, the bolted connection of the 
body sheet can be represented as a multi-element system, the failure of each element of which leads to the formation of a new design scheme of the joint and thus provokes a change in the reliability of the whole connection.

The general concept of a stochastic calculation will be based on the use of the Monte-Carlo simulation procedure for samples of the random variables $\gamma_{R, i}$ and $\gamma_{S, i}$ of the large volume [15]. For the critical factor of the basic metal of the sheets of the silo body, the following ratio will be valid

$$
K_{R, i}=\frac{m_{S}}{m_{R}} \cdot \frac{1+\gamma_{S, i} V_{S}}{1+\gamma_{R, i} V_{R}}=m_{K} \cdot \gamma_{K, i},
$$

where $m_{S}$ and $m_{R}$ - mathematical expectations of random variables $\tilde{S}$ and $\tilde{R}$;

$\tilde{\gamma}_{R}$ and $\tilde{\gamma}_{S}$ - the normalized random variables with a given distribution law;

$V_{R}$ and $V_{S}$ - the coefficients of variation of strength and load;

$m_{K}$ - the expected value of a critical factor.

In the design case of a homogeneous bolted connection, when all bolts of the system are elements of one sample, the critical factor of the metal of bolts $\tilde{K}_{b, i}$ is expressed by the following expression [14]:

$$
\begin{aligned}
& \tilde{K}_{b, i}=\frac{\tilde{S}_{i}}{\tilde{R}_{b s, i} \cdot A_{b} \cdot n}=m_{b} \cdot \frac{1+V_{S} \tilde{\gamma}_{S, i}}{1+V_{b s} \tilde{\gamma}_{b s, i}} \\
& m_{b}=\frac{1,273}{d_{b}^{2} \cdot n} \cdot \frac{m_{S}}{m_{b s}}
\end{aligned}
$$

where $\tilde{R}_{b s, i}$ - the random value of the strength of one bolt per cut;

$A_{b}$ - the value of the area of the bolts;

$d_{b}$ - the diameter of the bolt;

$n$ - the number of elements (bolts) of the sample;

$m_{S}, m_{b s}$ and $V_{S}, V_{b s}$ - respectively the values of the expected value and coefficients of variation of the random variables $\tilde{S}_{i}$ and $\tilde{R}_{b s, i}$;

$\tilde{\gamma}_{b s, i}$ - the normalized random value of the strength of the bolt;

$\tilde{\gamma}_{S, i}$ - the value of the normalized random value of maximums of the external force, which influence the connection.

The problem of stochastic calculation of a quasi-homogeneous bolted joint, when the bolts of connection consist of two independent samples $n=n_{1}+n_{2}$, has been considered in studies of the group of authors [14]. We also should consider the design situation where the bolts of connection consist of three independent samples $n=n_{1}+n_{2}+n_{3}$.

This case will illustrate the change in system reliability when there are coupled three types of fasteners in a unit connection, such as bolts of different strength classes or different manufacturing plants.
The use of expression (3), taking into account the corresponding values of the expected value $m_{b}$ and the coefficient of variation $V_{b s}$, will be valid only in cases $\tilde{K}_{b, i}<1,0$, ie., before the failure

$$
\tilde{K}_{b, i}=\frac{\tilde{S}_{i}}{A_{b} \cdot\left(\tilde{R}_{b s 1, i} \cdot n_{1}+\tilde{R}_{b s 2, i} \cdot n_{2}+\tilde{R}_{b s 3, i} \cdot n_{3}\right)} .
$$

If there is a connection failure, a critical factor exceeded the single-level. This process can be implemented according to different schemes, each of them should be considered when calculating a random value of the critical factor. For the simplest connection of the three bolts, the random strength of which in the space of effort is corresponding to $\tilde{S}_{01}, \tilde{S}_{02}$ and $\tilde{S}_{03}$ the reliability of the connection will be ensured if the following demands are made for the $i$-th sample element:

1) the value of the random strength of each of the three bolts $\tilde{S}_{01, i} \vee \tilde{S}_{02, i} \vee \tilde{S}_{03, i}$ will be bigger than the force $\tilde{S}_{i} / 3$;

2) the strength of one of the bolts is less than $\tilde{S}_{i} / 3$ and it is ruined, but the strength of the remaining two ones is bigger than $\tilde{S}_{i} / 2$;

3 ) the strength of two bolts is less than $\tilde{S}_{i} / 3$, and of the third one is bigger than $\tilde{S}_{i}$;

4) the strength of one bolt is bigger than $\tilde{S}_{i} / 3$ but less $\tilde{S}_{i} / 2$; the strength of the second bolt is bigger than $\tilde{S}_{i} / 2$ and of the third one is bigger than $\tilde{S}_{i}$.

In this case, we will get a system of conditions for a critical factor:

I - the strength of all bolts is less than $\tilde{S}_{i} / 3$;

II... IV - strength of one of the bolts is less than $\tilde{S}_{i} / 3$ ;

V... VII - the effort $\tilde{S}_{i} / 3$ in both bolts simultaneously exaggerates their bearing capacity;

VIII - the bearing capacity of all bolts is less than $\tilde{S}_{i} / 3$.

This system can generally be schematized by the expression (6), where for values $\tilde{K}_{b 12, i}, \tilde{K}_{b 13, i}$ and $\tilde{K}_{b 23, i}$ we will apply the term «conditional» critical factors. These random variables will be calculated just as for the case of connecting elements from two independent samples, which were described in the paper 


$$
\tilde{K}_{b, i}=\mid \begin{array}{cll}
\tilde{S}_{i} /\left(\tilde{S}_{01, i}+\tilde{S}_{02, i}+\tilde{S}_{03, i}\right), & \text { if } \quad \tilde{S}_{i} / \tilde{S}_{01, i}<3 \wedge \tilde{S}_{i} / \tilde{S}_{02, i}<3 \wedge \tilde{S}_{i} / \tilde{S}_{03, i}<3 \\
\tilde{K}_{b 12, i}, & \text { if } \quad \tilde{S}_{i} / \tilde{S}_{01, i}<3 \wedge \tilde{S}_{i} / \tilde{S}_{02, i}<3 \wedge \tilde{S}_{i} / \tilde{S}_{03, i} \geq 3 \\
\tilde{K}_{b 13, i}, & \text { if } \quad \tilde{S}_{i} / \tilde{S}_{01, i}<3 \wedge \tilde{S}_{i} / \tilde{S}_{02, i} \geq 3 \wedge \tilde{S}_{i} / \tilde{S}_{03, i}<3 \\
\tilde{K}_{b 23, i}, & \text { if } \quad \tilde{S}_{i} / \tilde{S}_{01, i} \geq 3 \wedge \tilde{S}_{i} / \tilde{S}_{02, i}<3 \wedge \tilde{S}_{i} / \tilde{S}_{03, i}<3 \\
\tilde{S}_{i} / \tilde{S}_{01, i}, & \text { if } \quad \tilde{S}_{i} / \tilde{S}_{01, i}<3 \wedge \tilde{S}_{i} / \tilde{S}_{02, i} \geq 3 \wedge \tilde{S}_{i} / \tilde{S}_{03, i} \geq 3 \\
\tilde{S}_{i} / \tilde{S}_{02, i}, & \text { if } \quad \tilde{S}_{i} / \tilde{S}_{01, i} \geq 3 \wedge \tilde{S}_{i} / \tilde{S}_{02, i}<3 \wedge \tilde{S}_{i} / \tilde{S}_{03, i} \geq 3 \\
\tilde{S}_{i} / \tilde{S}_{03, i}, & \text { if } \quad \tilde{S}_{i} / \tilde{S}_{01, i} \geq 3 \wedge \tilde{S}_{i} / \tilde{S}_{02, i} \geq 3 \wedge \tilde{S}_{i} / \tilde{S}_{03, i}<3 \\
\tilde{S}_{i} /\left(\tilde{S}_{01, i}+\tilde{S}_{02, i}+\tilde{S}_{03, i}\right), & \text { if } \quad \tilde{S}_{i} / \tilde{S}_{01, i} \geq 3 \wedge \tilde{S}_{i} / \tilde{S}_{02, i} \geq 3 \wedge \tilde{S}_{i} / \tilde{S}_{03, i} \geq 3,
\end{array}
$$

Also, in order to find the values of conditional critical factors, based on the general expression (3), we can obtain the following formulas:

$$
\begin{gathered}
\tilde{K}_{b 1, i}=\mathrm{M}_{b, 1} \cdot \frac{1+V_{S} \tilde{\gamma}_{S, i}}{1+V_{b s 1} \tilde{\gamma}_{b s 1, i}} ; \\
\tilde{K}_{b 2, i}=\mathrm{M}_{b, 2} \cdot \frac{1+V_{S} \tilde{\gamma}_{S, i}}{1+V_{b s 2} \tilde{\gamma}_{b s 2, i}} .
\end{gathered}
$$

The magnitudes of the expected value and the coefficient of variation of the critical factor, when calculated by formulas (7) and (8), will acquire a new presentation:

$$
\begin{gathered}
m_{b, i}=\mathrm{M}_{b} \cdot \frac{1}{\alpha_{b, i}+\beta_{b, i} \eta_{b s}} ; \\
V_{b s, i}=\frac{\sqrt{\alpha_{b, i}^{2} V_{b s 1}^{2}+\beta_{b, i}^{2} V_{b s 2}^{2} \eta_{b s}^{2}}}{\alpha_{b, i}+\beta_{b, i} \eta_{b s}}
\end{gathered}
$$

where $\eta_{b s}=\frac{m_{b s 2} n_{2}}{m_{b s 1} n_{1}}-$ the ratio of the characteristics and the number of bolts.

The values of the coefficients $\alpha_{b, i}$ and $\beta_{b, i}$,which appear in (9) and (10) will be determined from the following conditions

$$
\begin{aligned}
\alpha_{b, i} & =\mid \begin{array}{lll}
1, & \text { if } & \tilde{K}_{b 1, i}<2 \wedge \tilde{K}_{b 2, i}<2 ; \\
1, & \text { if } & \tilde{K}_{b 1, i}<2 \wedge \tilde{K}_{b 2, i} \geq 2 ; \\
0, & \text { if } & \tilde{K}_{b 1, i} \geq 2 \wedge \tilde{K}_{b 2, i}<2 ; \\
1, & \text { if } & \tilde{K}_{b 1, i} \geq 2 \wedge \tilde{K}_{b 2, i} \geq 2 .
\end{array} \\
\beta_{b, i} & =\mid \begin{array}{lll}
1, & \text { if } & \tilde{K}_{b 1, i}<2 \wedge \tilde{K}_{b 2, i}<2 ; \\
0, & \text { if } & \tilde{K}_{b 1, i}<2 \wedge \tilde{K}_{b 2, i} \geq 2 ; \\
1, & \text { if } & \tilde{K}_{b 1, i} \geq 2 \wedge \tilde{K}_{b 2, i}<2 ; \\
1, & \text { if } & \tilde{K}_{b 1, i} \geq 2 \wedge \tilde{K}_{b 2, i} \geq 2 .
\end{array}
\end{aligned}
$$

To illustrate the calculation procedure for the search of the coefficient of the critical factor of a three-element bolted joint, we will do a practical example of calculation with the following graphical presentation. The calculation will be performed accordingly to the following initial characteristics of the system - the bolted joint receives the action of a random force, with the expected value $m_{S}=200 \mathrm{kN}$ and with one of the three values of the coefficient of variation $V_{S}=0,2 \vee 0,4 \vee 0,6$. The distribution density of the probabilities is assumed as a double exponential law. The bearing capacity of all three bolts is determined by a normal law, but with different statistical characteristics: for the first bolt $m_{S, 01}=250 \mathrm{kN}$, for the second one $-m_{S, 02}=200 \mathrm{kN}$, and for the third one $-m_{S, 03}=150 \mathrm{kN}$. The range of the coefficients' changing of the bearing capacity of all bolts is accepted as $V_{S}=0,05 \vee 0,1 \vee 0,2$.

The reliability assessment will be performed on a special coordinate plane - the critical probability scale, on the $y$-axis of which we put the values of a random variable of a critical factor, and on the $\mathrm{x}$-axis - the double natural logarithm of the probability of the failure-free work

$$
y=-\ln \left[-\ln \left(F_{\gamma}\right)\right],
$$

where $F_{\gamma}$ - the probability of a failure-free work, which is calculated using the formula $[14,15]$

$$
F_{\gamma}=\exp \left[-\exp \left(\frac{\alpha_{B}-\sqrt{\alpha_{B}^{2}-4 \alpha_{A}^{2}\left(1-\alpha_{C} V_{S}-1 / m_{K}\right)}}{2 \alpha_{A}}\right)\right],
$$

where $\alpha_{A}, \alpha_{B}$ and $\alpha_{C}$-dimensionless coefficients, which consider the influence of the coefficient of variation of the bearing capacity and the law of maximums' distribution of a random load. For the load distribution, accordingly to the normal law of distribution $\alpha_{A} \approx-0,02, \alpha_{B} \approx 0,65, \alpha_{C} \approx 0,18$, and for the double exponential Humbel law $\alpha_{A} \approx 0, \alpha_{B} \approx 0,84$, $\alpha_{C} \approx 0,57$.

This allows comparing data across a wide range of a failure-free work.

The resulting curves of change of the critical factor are shown on the fig. 2, which have the graphs of three kinds on the coordinate plane.

The curves plotted with a solid thick line correspond to the reference functions of the critical factor.

The graphs, which are illustrated by dots, are the functions that are constructed by formula (6) without considering the calculations of conditional critical factors, i.e., it is considered the process of failure of one bolt in joint with the two others, but the mechanism of failure of one bolt of the joint is not taking into account.

Dotted curves are the values of the critical factor calculated in case of absence of any sequence of failure of the bolts in the joint.

Observing the nature of the change in the curves (fig. 2 ), we can see clearly an error, which arises in case of fully neglecting the sequence of the bolts' failure in the joint.

It is logical that the greatest differences occur between the solid and the dotted curves. 
a)

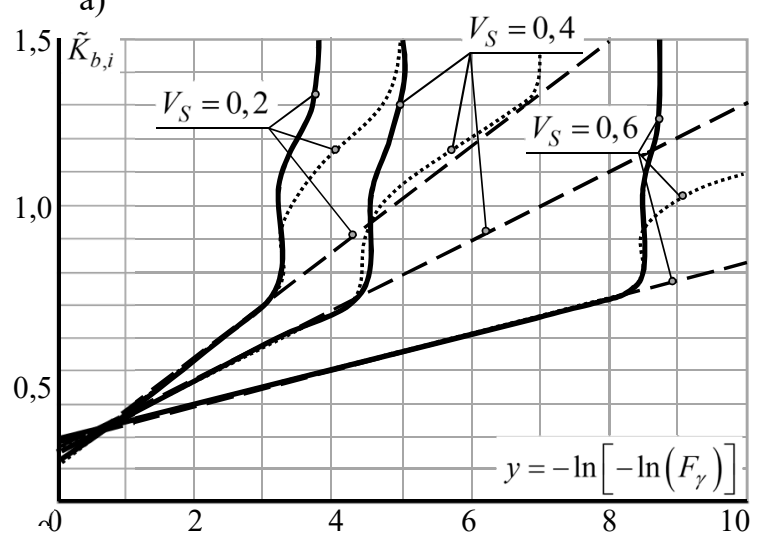

b)

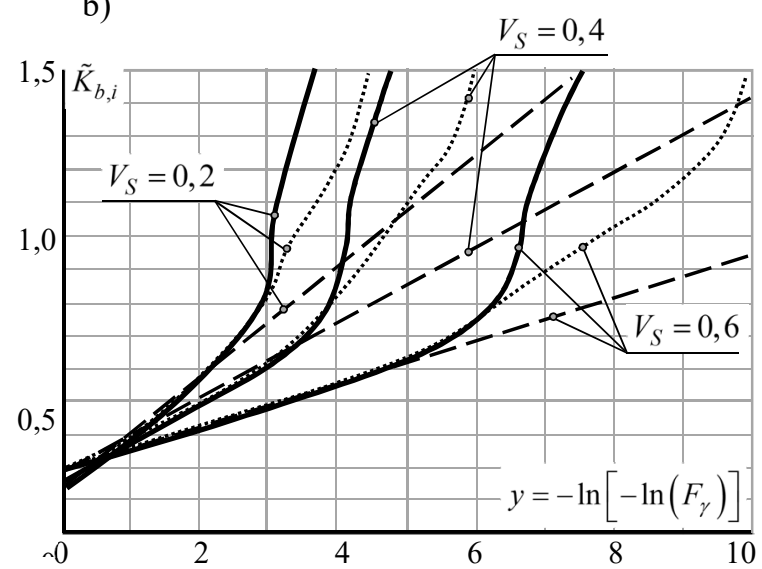

Figure 2 - Probability of a failure-free work of the joint of three bolts on a critical probability scale:

$\mathrm{a}-V_{R, 01}=V_{R, 02}=V_{R, 03}=0,05 ; V_{S}=0,2 \vee 0,4 \vee 0,6$;

$\mathrm{b}-V_{R, 01}=V_{R, 02}=V_{R, 03}=0,2 ; V_{S}=0,2 \vee 0,4 \vee 0,6$

The difference between solid and pointed curves is not so significant and does not increase in case of insignificant variability of the bolted strength, even if there are large values of the coefficient of variation of the external force. This is especially noticeable when comparing the behavior of the curves not in the entire coordinate plane, but only in the vicinity of the ordinate $K_{b}=$ 1 , for value of which the probability of a failure-free work is calculated.

Figure 2 also shows that the curves $\tilde{K}_{b, i}$ have three inflection points. However, the smaller the variability of the strength of the bolt is, the clearer the given point could be tracked and the greater is the angle of the curves to the horizontal axis. At large values of the coefficient of variation of the strength the curves of the critical factor are smoother in nature, and the points of inflection of the curves are almost imperceptible. Considering this, it can be assumed that the dependence of the critical factor from the logarithmic reliability index will always have as many inflection points as the bolts of different statistical characteristics, which are included in the joint. It should only be noted that the random values of the strength of the bolts must be independent.
Also, we consider that with small coefficients of variation of the force values and the different coefficients of variation of the strength of the bolts, the index of the probability of failure-free work of the joint is very close and differs only when $V_{s}>0,5$. Of course, the biggest role plays also the ratio of expected value, but for highly reliable systems we can also use this tendency.

When there is the absence of variability of the strength values of the bolts on the critical probability scale, the inclined sections of the curves between the points of inflection turn into vertical segments (fig. 3).

Thus, we can state that the random value of the critical factor increases when there is the constant value of the reliability index.

If the expected value of the bolt strength is equal, then the curve of the critical factor must be constructed accordingly to the formula (3).

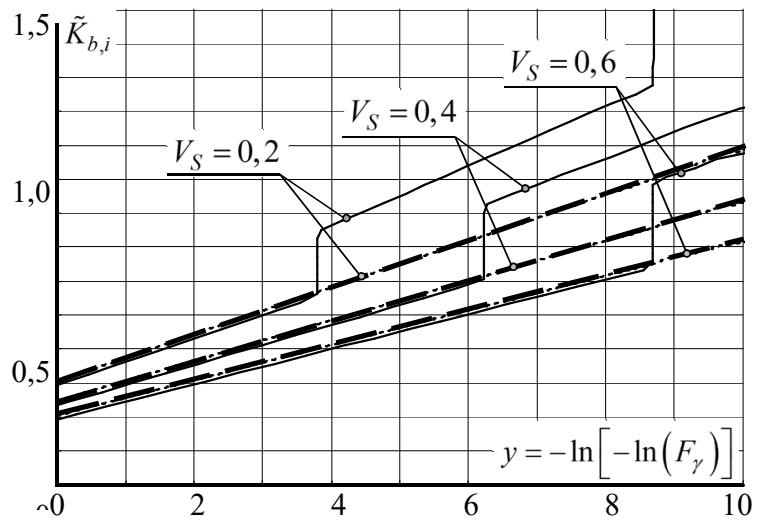

Figure 3 - Probability of a failure-free work of the joint of three bolts on critical probability scale in case of absence variability of the strength of the bolts

\section{Conclusions}

1. As part of the study, it was further developed the method for assessing the reliability of multi-bolt joints of the body sheets of steel cylindrical silos for situations when bolts in the mounting joint can belong to the three strength classes.

2. It was obtained the system of conditions and analytical dependencies for the calculation of the critical factor coefficient.

3. Using the example of graphical construction of the curves of the coefficients of the critical factor for different cases of failure sequences, it was illustrated that accidental presence of bolts of smaller strength classes in the mounting joint rapidly increases the risk of failure.

4. It was found that the index of probability of failurefree work of the homogeneous and quasi-homogeneous bolted joints begin to differ only when the coefficients of variation of the force value $V_{s}>0,5$ increase.

5. Even if there is the absence of variability of values of the bolt strength, the random value of the critical factor will be increased accordingly to a constant value of the reliability index. 


\section{References}

1. Elliott, M.D., Teh, L.H. \& Ahmed, A. (2019). Behaviour and strength of bolted connections failing in shear. Journal of Constructional Steel Research, 153, 320329.

https://doi.org/10.1016/j.jcsr.2018.10.029

2. Bryan, E.R. (1993). The design of bolted joints in coldformed steel sections. Thin-Walled Structures, 16, 1-4, 239-262.

https://doi.org/10.1016/0263-8231(93)90047-E

3. Gao, D., Yao, W. \& Wu, T. (2019). Failure analysis on the axial-connected bolts of the thin-walled cylinder under random vibration loading. Engineering Failure Analysis, $105,756-765$.

https://doi.org/10.1016/j.engfailanal.2019.06.043

4. Zaroug, M.El., Kadioglu, F., Demiral, M. \& Saad, D. (2018). Experimental and numerical investigation into strength of bolted, bonded and hybrid single lap joints: Effects of adherend material type and thickness. International Journal of Adhesion and Adhesives, 87, 30-141. https://doi.org/10.1016/j.ijadhadh.2018.10.006

5. Атрошенко, А.А. (2016). Анализ конструкционной прочности составных тонкостенных конструкиий с болтовым соединением элементов. Харьков, НТУХПИ.

6. Chung, K.F. \& Ip, K.H. (2001). Finite element investigation on the structural behaviour of cold-formed steel bolted connections. Engineering structures, 23,9, 11151125.

https://doi.org/10.1016/S0141-0296(01)00006-2

7. Tang, G., Yin, L., Guo, X. \& Cui, J. (2015). Finite element analysis and experimental research on mechanical performance of bolt connections of corrugated steel plates. International Journal of Steel Structures, 15,1, 193-204.

https://doi.org/10.1007/s13296-015-3014-4

8. Shi, Y., Wang, M. \&Wang, Y. (2011). Analysis on shear behavior of high-strength bolts connection. International Journal of Steel Structures, 11,2, 203-213.

https://doi.org/10.1007/s13296-011-2008-0

9. Перельмутер, А.В. (2007). Избранные проблемы надежности и безопасности строительных конструкций. Москва : АСВ

10. Райзер, В.Д. (1995). Расчет и нормирование надежности строительных конструкиий. Москва: Стройиздат.

11. Пичугин, С.Ф. (2009). Надёжность стальных конструкиий производственных зданий: монография. Полтава: АСМИ.

12. Pichugin, S. \& Makhinko, A. (2009). Calculation of the reliability of steel underground pipelines. Strength of Materials, 41(5), 541-547.

13. Pichugin, S. \& Makhinko, N. (2019). Using of High Strength Steel for Constructions of Vertical Silo Capacities. Academic journal. Industrial Machine Building, Civil Engineering, 1(51), 51-57.

14. Пічугін, С., Махінько, Н. (2019). Оцінка надійності багатоболтових з'єднань стінки силосної ємності. Збірник наукових прачь за матеріалами II Міжнародноі украӥно-азербайджанської конф.: Building Innovations 2019, 176-178.

15. Махінько, Н.О. (2019). Імовірнісне представлення коефіцієнта критичного фактору в задачах надійності будівельних конструкцій. Наука та будівниитво, 2, $56-61$
1. Elliott, M.D., Teh, L.H. \& Ahmed, A. (2019). Behaviour and strength of bolted connections failing in shear. Journal of Constructional Steel Research, 153, 320-329.

https://doi.org/10.1016/j.jcsr.2018.10.029

2. Bryan, E.R. (1993). The design of bolted joints in coldformed steel sections. Thin-Walled Structures, 16, 1-4, 239-262.

https://doi.org/10.1016/0263-8231(93)90047-E

3. Gao, D., Yao, W. \& Wu, T. (2019). Failure analysis on the axial-connected bolts of the thin-walled cylinder under random vibration loading. Engineering Failure Analysis, 105, 756-765.

https://doi.org/10.1016/j.engfailanal.2019.06.043

4. Zaroug, M.El., Kadioglu, F., Demiral, M. \& Saad, D. (2018). Experimental and numerical investigation into strength of bolted, bonded and hybrid single lap joints: Effects of adherend material type and thickness. International Journal of Adhesion and Adhesives, 87, 30-141.

https://doi.org/10.1016/j.ijadhadh.2018.10.006

5. Atroshenko, A.A. (2016). Analysis of structural strength of composite thin-walled structures with bolted connection of elements. Kharkov, NTUKHPI.

6. Chung, K.F. \& Ip, K.H. (2001). Finite element investigation on the structural behaviour of cold-formed steel bolted connections. Engineering structures, 23,9, 11151125

https://doi.org/10.1016/S0141-0296(01)00006-2

7. Tang, G., Yin, L., Guo, X. \& Cui, J. (2015). Finite element analysis and experimental research on mechanical performance of bolt connections of corrugated steel plates. International Journal of Steel Structures, 15,1, 193-204.

https://doi.org/10.1007/s13296-015-3014-4

8. Shi, Y., Wang, M. \& Wang, Y. (2011). Analysis on shear behavior of high-strength bolts connection. International Journal of Steel Structures, 11,2, 203-213.

https://doi.org/10.1007/s13296-011-2008-0

9. Perelmuter, A.V. (2007). Selected problems of civil structures reliability and safety. Moscow: ASV.

10. Raizer, V.D. (1995). Calculation and standardization of the reliability of building structures. Moscow: Stroiizdat.

11. Pichugin, S.F. (2009). Reliability of industrial buildings civil structures: monografiia. Poltava: ASMI.

12. Pichugin, S. \& Makhinko, A. (2009). Calculation of the reliability of steel underground pipelines. Strength of Materials, 41(5), 541-547.

13. Pichugin, S. \& Makhinko, N. (2019). Using of High Strength Steel for Constructions of Vertical Silo Capacities. Academic journal. Industrial Machine Building, Civil Engineering, 1(51), 51-57.

14. Pichugin, S. \& Makhinko, N. (2019). The reliability assessment of multibolt joints of the silo capacity's wall. Proceedings of the International Ukr.-Azerbaijani Conf.: Building Innovations - 2019, 176-178.

15. Makhinko, N. (2019). Stochastic representation of the critical factor coefficient in the reliability problems of the building structures. Science and Construction, 2, 56-61. 